\title{
THE ROLE OF REPENTANCE OF CONVICTS IN THE PROCESS OF THEIR CORRECTION AND RESOCIALIZATION
}

\author{
Nataliia Klishevich \\ Borys Grinchenko Kyiv University, Ukraine \\ Vadym Sulitskyi \\ Borys Grinchenko Kyiv University, Ukraine
}

\begin{abstract}
At present, the humanization of the State Penitentiary Service of Ukraine is carried out through the development and implementation of milder measures of punishment, reduction of sentences for certain crimes, the introduction of alternatives to imprisonment, such as probation. All this requires more serious and comprehensive socio-psychological research on the development and implementation of a wide range of pedagogical and socio-psychological methods of influencing the personality, group, team of convicts. Promising, in our opinion, is the psychological change in the personality of the convict by bringing him to sincere conscious repentance, reconciliation with the victim. This approach will help to correct the convict and positively influence his resocialization and create conditions for successful socialization. The purpose of our study was to determine the role and place of repentance in the process of serving a sentence by convicts and to identify the positive impact of repentance on correction and resocialization, reducing the risk of repeated wrongful acts by persons serving sentences in penal institutions. To achieve this goal, we used the following methods: analysis of scientific literature, observation, questioning, psychodiagnostics testing, extended interviews.

The study was conducted in the period from 2010 to 2016 in the correctional colonies of the Donetsk region. It was attended by 3,400 clients of correctional system and 280 employees of penitentiary institutions. In the course of our research, we discovered: at present, views on the concept of "repentance" can be divided into creative, religious, philosophical, sociopsychological, pedagogical, legal; the legal interpretation of the concept of "effective repentance" and its application in the practice of justice revealed a number of problems that require solution; repentance in the psychological and pedagogical sense can be viewed as: an integral part of moral self-improvement; the acquisition of a new spiritual, moral, psychological quality of the person; the life position of the individual in relation to the world, people, his own place in life; the formation of other positive, socially recognized values; an indicator of moral maturity, spiritual and mental health.

In this article we offer our own view on the role and place of repentance in the process of correction and resocialization of clients of correctional system. Scientific research of this problem is very important in a methodological sense not only for the penitentiary service, including the work of psychologists in penitentiary institutions, but also for social educators and social workers. It will contribute to the solution of general and special issues of the psychological and pedagogical process of the execution of sentences by employees of
\end{abstract}


Klishevich \& Sulitskyi, 2021. The Role of Repentance of Convicts in the Process of their Correction and Resocialization

penitentiary institutions and the social and psychological process of serving sentences by convicts, will help create reliable conditions for the protection of human rights, civil liberties, including people who are serving sentences.

Keywords: convicted; correction; execution of a sentence; process; repentance; preparation of convicts for life at large; serving a sentence.

\section{Introduction}

It should be noted that the foundations of changes in state policy in the field of enforcement of sentences and treatment of convicts are reflected in new changes in criminal, criminal procedural, criminal-executive legislation and practice of enforcement of sentences. These changes cannot be called radical, since they were carried out and are being implemented on the normative and material basis of the State Penitentiary Service of Ukraine, received and acquired over the past years of independence. The staff of correctional colonies, who have outdated views on the processes of execution and serving of sentences, are not ready to work in new conditions, to apply the latest forms and methods of working with convicts. The exception is those provisions of the legislation that contradicted international standards and did not fit into the new socio-economic, legal, social conditions of life and relations.

Humanization of the State Penitentiary Service of Ukraine, according to our forecasts, will be carried out through the development and implementation of softer punishments, reduction of sentences for certain crimes, introduction of alternatives to imprisonment, for example, conditionally. All this requires more serious and complex socio-psychological research on the development and implementation of a wide range of socio-pedagogical and psychological methods of influencing the individual, group, collective of convicts. Promising, in our opinion, is the psychological change in the personality of the convict by bringing him to a sincere conscious repentance, reconciliation with the victim. Such a scientific approach will help to correct the convict, positively affect his resocialization and create conditions for successful socialization.

Analysis of scientific literature allows us to identify the following approaches to "repentance": culturological; religious; philosophical; psychological and pedagogical; legal aspect.

The culturological approach considers repentance as purification and spiritual improvement of the individual. Human suffering in the process of repentance is an important attribute of works of art. It is literature that helps to understand the meaning of life, make the right choice, understand the difference between good and evil, admit your guilt, sincerely repent and correct your mistakes. In working with convicts, this approach is embodied in bibliotherapy (Aleksejchik, 1985; Jack \& Ronan, 2008; McCulliss, 2012). 
The religious approach regards repentance as the main church sacrament and one of the important moral categories of Christianity. This is mentioned many times in biblical texts or postulates of repentance (Yaroshovec, Bichko, \& Bugrov, 2006). The parable of the prodigal son should be especially noted as an example of a person's inner self-improvement through repentance (Smirnov \& Chikina, 2016). We see the influence of repentance on human destiny in the analysis of theological works (Ubyali, 2009; Vorkachev, 2012). Today, churches, chapels and prayer rooms function in almost every penitentiary institution. The convicts are attended by priests and services.

A philosophical approach to repentance is presented by works (Ilyin, 1943; Smirnov, 2005; Shadrikov, 2006; Maslova, 2016; Tupikova, 2016), which considered repentance as an act of moral reflection in the process of forming conscience.

The legal approach looks at repentance in terms of its effectiveness. According to Antonyan (1991a, 1996b), Sevastyanov (2015), Pakhomov \& Grigorenko (2019), repentance is a person's awareness of his negative actions, his moral shortcomings, recognition of his mistakes and sincere sympathy for them. It is accompanied by a firm intention not to repeat offenses and to take action to eliminate their consequences, and sometimes to impose punishment. Thus, the chain of immoral actions is interrupted. Repentance can atone for a crime, but not justify it. And it becomes clear how important repentance is for the purification of the values of society, the spiritual development of the nation and the individual, and, especially, the prevention of crime (Yakovets, 2016).

We are interested in repentance from the point of view of constructive changes in the personality of convicts, as a condition for their further resocialization and socialization, and a decrease in crime. Scientific research of this problem is of great methodological importance not only for the social and educational service of penitentiary institutions, the activities of social educators and psychologists of penitentiary institutions, but also for social pedagogy, social psychology, penitentiary pedagogy and penitentiary psychology. It will help to solve general and specific issues of the educational process of convicts with a view to their return to society and will help to create reliable conditions for the protection of human and civil rights and freedoms, including the convict, as well as the interests of society, protected by law. Our research will greatly facilitate the solution of issues related to assessing the risks of relapse of convicts, parole, imprisonment, amnesty and pardon.

\section{Methodology}

The aim of our study was to determine how repentance in convicts affects their correction and resocialization, reducing the risk of repeated unlawful actions 
in the process of serving a sentence and after being released from prison. To achieve this goal, we used the following methods: observation, questionnaires, psychodiagnostics testing, extended interviews.

Our research took place in four stages. At the first stage, we used a questionnaire that we developed. The questionnaire included four blocks of questions that allow us to establish the attitude of the convicts: block $1-$ to a crime, investigation, trial, term of punishment; block 2 - to the victim, the consequences of the crime, family, parents; block 3 - serve a sentence in a correctional institution; block 4 - for yourself, life, future, death, society. At the second stage, a study was carried out using the psychodiagnostics methodology "Assessment of the degree of convict's confession of his guilt" (Kvachev, Sukhinskaya \& Tatarevsky, 2014). She helped us assess the sincerity of the convicts' admission of their guilt. In an extended interview, we received additional information about the convict, his crime, social connections, plans for the future, values, and assessments of his crime.

The third stage consisted of observing the respondents and analyzing the independent characteristics of the convicts. To obtain information about the convicts, employees of penitentiary institutions were involved in the survey.

At the fourth stage, extended interviews with convicts were conducted. It was important for us to understand what meaning is put into the concept of "repentance", how convicts assess repentance during the execution of punishments, how their behavior, attitudes towards themselves, the victim, crime, moral norms and society change after full admission of guilt and repentance for their unlawful acts. The results obtained helped to develop their own idea of the role of the convict's repentance in the process of reforming and preparing convicts for life in freedom.

The study was conducted in the period from 2010 to 2016 in the correctional colonies of the Donetsk region. It was attended by 3,400 subjects of the correctional system and 280 employees of penitentiary institutions.

\section{Research Results}

We believe that repentance is an indicator of moral maturity, spiritual and mental health of a person. It includes many aspects of life, namely: the vision of one's own guilt, hatred for it, pity and compassion for the victim (victims and victims), shame for the crime and its consequences, sincerity in feelings, the desire to atone for moral and material damage.

Based on the results of questioning convicts about their attitude to the crime, we received the following data:

- $\quad$ only $3 \%$ of them experienced a feeling of remorse, remorse and remorse for a crime and its consequences for victims; 
- $\quad$ almost $90 \%$ of the convicted pleaded guilty, but $88 \%$ did not express regret about the violation of the law;

- $\quad 12 \%$ regretted what they had done, but had feelings only for the lengthy sentence passed by the court;

- before committing a crime, only $19 \%$ foresaw the possible consequences and future punishment, including imprisonment. 81\% of the convicts did not think about the crime, did not feel remorse, did not feel personal guilt, and did not imagine the consequences of their own responsibility before the law and society. This fact can be explained by the fact that $86 \%$ of convicts who were under investigation committed a crime (crimes) in a state of alcoholic or drug intoxication;

- $\quad 79 \%$ of those convicted of a crime blame friends, relatives, victim, investigation, judge, prosecutor, "hard life", but not themselves;

- there is one peculiarity: with full admission of guilt and acceptance of punishment, $99 \%$ of convicts consider themselves "victims of circumstances";

- $\quad 1 \%$ responded adequately to the crime, its consequences, punishment, conditions of serving the sentence, difficulties of socialization after release. This percentage is made up of former convicts who have already been in prison once. They don't want to get there anymore.

Thus, the sincere conscious repentance of the convict (structural-logical scheme) consists, in our opinion, of the following elements: attitude towards oneself, attitude towards others, attitude towards life, attitude towards the future, attitude towards society, attitude towards crime, attitude towards consequences crimes, attitude towards punishment, attitude towards preparation for life in conditions of freedom and socialization.

- $76 \%$ of convicts admit their guilt purely formally. We saw no audiovisual signs of genuine conscious remorse, but there were signs of concern for our own future.

- $\quad$ The used psychodiagnostics technique allowed us to establish several patterns:

- $\quad$ the desire of convicts to abandon their own crime;

- evasion from moral and spiritual assessment of the crime due to the traumatic consequences for oneself of such assessments;

- focusing on the relationship of various external factors and the consequences of their socially dangerous actions;

- $\quad$ reduce your role in the crime and try not to feel the consequences of the crime on yourself: "Yes, he was, but he is not to blame!!!"

Modern Ukrainian society is going through a crisis, the components of which are: a weak inclination to moral purification, spiritual self-improvement, 
repentance. Any manifestations of conscience (repentance as an integral part of conscience, considered as an integral substructure of the psychological structure of a person along with abilities and charactering our "corporate society" are strongly repelled and considered "mutual responsibility". The environment of convicts, especially those serving sentences in prisons, is no exception. Our opinion coincides with the opinion of other scientists (Suprun, 2019; Pakhomov \& Grigorenko, 2019).

On the basis of the general results of the research, we offer our view on the role and place of repentance in social psychology and pedagogy.

Let's start with the relationship between the two categories, which, at first glance, are not directly related to psychology. They are more philosophical. However, psychology owes its birth to this science, and all its origins begin with it. These are the categories "good" and "evil".

The concepts of "good" and "evil" are conditional and relative, this is only a projection of our desires onto the inner duality of any object. The main problem of good and evil is human choice. When the question arises of what exactly was the person (the convicted person) guided in this own action - reason or feelings, then in reality everything is completely different: was he guided by small, narrow, situational, personal guidelines or guidelines. Which were conditioned and were outside the situation, covering a significant period of time, milestones on the scale of a large imprint of time or even life. Thus, repentance is an integral state of a person's involvement in the "existence of the world", which reflects the degree of coincidence of the existence and essence of a person. It is the act of a person's self-esteem in situations of moral choice.

In our case, "good" is atonement, sincere, conscious repentance, and evil is a crime and its consequences.

To better understand our train of thought, we offer a step-by-step sociopedagogical model of repentance.

Stage 1 - the ratio of "good" and "evil". It consists of: the process of knowing the difference between good and evil; the process of understanding this difference; the process of understanding the concepts of "good" and "evil"; stable installation in one of these categories; actions (behavior); result and the difference between one's own assessment of the crime and the assessment of society.

As you can see, the relationship between good and evil is a cognitive process and a process of voluntary choice by convicts for further actions for any purpose. However, the distance between "knowledge" and "conscious attitude" to any action has two more intermediate results - understanding (for example: I know that stealing is annoying, but I do not understand why) and realizing (stealing is annoying because it harms the victim, but for me the result is positive, because I do not take into account the consequences: investigation, trial, conclusion). The conscious attitude is the final product of the cognitive process of the individual 
and the first step towards action. The conclusion in this case determines the person's intention to commit or not to commit a crime. He is influenced by his own assessment of the action and the perception of its consequences, as well as public assessment of the action and its results.

Self-assessment of an action (VO) - justification of a committed crime by reasons not related to its results and consequences (temporary enrichment, elimination of the victim, revenge, etc.).

Public assessment of the action (OS) is the reaction of society to the nature of the crime and its results or consequences (such a good person suffered, I really feel sorry for the victim, what a loss, etc.). However, the public assessment should be divided into: assessment of the close environment (family); assessment of the average environment (friends, comrades); assessment of the minimum-average environment (employees, neighbors, etc.); assessment of the maximum average environment (village, city, district); assessment of the remote environment (public response).

Let's consider the main types of $\mathrm{VO}$ and OS relations.

VO $>$ OS - in this case, the individual's own ambitions will defeat public opinion and the crime will be committed (impossible, but I want it, or I decided so);

$\mathrm{VO}=\mathrm{OS}$ - this ratio can have the following parameters:

1) $-\mathrm{VO}=-\mathrm{OS}$ - the crime will not be committed, since the actions and their results in both cases have a negative assessment;

2) $+\mathrm{VO}=-$ OS - in this case, the assessment of actions and their consequences is diametrically opposite, but their resonance has the same strength with the opposite sign, so the crime will be committed due to a positive assessment of the immediate environment. and middle environment;

3) $-\mathrm{VO}=+\mathrm{OS}$ - this is the case when society approves of a person's actions, but the one who performed them is dissatisfied with their consequences for himself;

4) $+\mathrm{VO}=+$ OS - this ratio can be called the "Robin Hood syndrome", when a positive assessment of criminal actions by society is justified and raised to the level of a "national hero" of a criminal. Here we observe a substitution of concepts: when actions and their consequences are replaced by slogans and projections, and this leads to a distortion of public opinion.

VO < OS - in this case, under the influence of public opinion, a person voluntarily refuses to commit a crime and looks for other ways and methods of solving his own problems. 
Klishevich \& Sulitskyi, 2021. The Role of Repentance of Convicts in the Process of their Correction and Resocialization

Thus, the first stage influences the convict's conclusions about the expediency or necessity of changing his behavior, and as a result, his motives are clarified.

Stage 2 - the formation of motives for further behavior. This stage consists in the completion of the previous cognitive process, taking into account certain socio-psychological qualities of the individual. It includes: the process of knowing the conclusion; the process of understanding the output; stable attitude to action; level of development / presence or absence of conscience; psychological condition; personality behavior.

The following features are present in the behavior: the search for a meeting with the victim, the desire to compensate for the damage, to obtain forgiveness, the desire to be useful, and so on.

Motives of behavior - evasion of punishment, condemnation of the victim, indirect or direct justification of their actions (rationalism); willingness to accept punishment, sympathy for the victim, condemnation of their own actions (irrationalism). The motives of the convict's repentance are the relationship between rationalism and irrationalism in reparations.

It is this attitude that allows us to view repentance as an action and as an internal psychological need of a person.

Our research, as a result of the analysis of independent characteristics and observation, helped to establish the following motives for the repentance of the condemned: repentance as a way to receive encouragement; repentance as a way to shorten the sentence; remorse as a way of parole; repentance as a way to find a positive psycho-emotional state and peace of mind; repentance as a way of reconciling with the victim; remorse as a way to compensate the victim for moral damage; remorse as a way to compensate the victim for material damage; repentance as a hidden form of revenge on the victim; repentance as a personal spiritual need.

Thus, repentance is a complex mental process that takes place in the integral substructure of the personality "conscience", which evaluates the actions of the past in relation to the reactions of its own psyche, radically changes behavior and life in general, gaining a psychological state of peace and meaning.

Repentance is the ratio of emotional and sensory assessment (ECHO) of one's own actions and their consequences to cognitive-logical assessment (CLO) of one's own actions.

ECHO > CLO - remorse; ECHO = CLO - complete repentance; ECHO < CLO is a complete excuse. CLO (-), ECHO (-) - the person understands that his actions are illegal (those that are subject to condemnation), and he experiences a negative psycho-emotional state (I insulted the girl and I am ashamed of my actions, as she is). CLO (+). ECHO $(+)-$ a person is completely satisfied with his own actions and their results, while experiencing complete psycho-emotional 
satisfaction (he did everything right, he is calm, his conscience is clear). CLO (-), ECHO (+) - a person negatively evaluates his own actions, but experiences psycho-emotional satisfaction with the results (he deceived a friend, but I have a lot of money left). CLO (+), ECHO (-) - the person is sure that he did the right thing, despite the psycho-emotional dissatisfaction with the results or consequences (he did the right thing, but was punished).

Repentance is a psycho-emotional state of a person, in which he condemns his own actions and their consequences, shows pity and compassion for the victim and wants to come to terms with her in the material and moral sense. The result of repentance is the inner revival of the personality, which manifests itself in behavior and attitude towards oneself, life, future, death, others (society).

As the results of the extended interviews show, the attainment of sincere, conscious repentance by convicts goes through three periods. The first period is an assessment of the relationship between crime and punishment, where a crime is a characteristic of actions on the scale of their severity in accordance with the Criminal Code of Ukraine, and punishment is the correspondence of a crime to a punishment established by a court. According to the results of our analysis of the research data, during this period, the convicted person's own assessment of the court's sentence takes place in comparison with his own assessment of the sentence. This partly confirms the findings of the study (Kvachev et al., 2014), but significantly expands the understanding of the perception of their own guilt and the terms of punishment by convicts.

Variants of perception by convicts of the term of punishment established by the court: I totally agree; I partially agree; I do not agree; partially disagree; I totally disagree, it's not my fault; the term of the sentence does not correspond to the degree of my fault; I believe that the sentence could have been shorter; the term of the sentence surprised my expectations; I thought the sentence would be longer; I need to be shot; "I deserve a life sentence.

The second period is the convicts' own assessment of their guilt. The results of testing and interviews with convicts are the same. Among the options for reporting a crime, we highlight the following: completely guilty; guilty; partially guilty; rather guilty than not guilty; rather innocent than guilty; not guilty; completely innocent; partially guilty; I am guilty, but I do not feel guilty; "I do not see" guilt in the crime; my actions are not a crime; guilty (not guilty), because ...; I do not regret what I did, but I am very sorry that I was caught; innocent, since the crime was a consequence of the circumstances in which I found myself; the one who pushed me to commit the crime is guilty; I am guilty before the state (society) to the same extent as it is guilty before me; not guilty, because I was slandered.

The third period consists of the following stages: adaptation (hidden motives to achieve their own goal); rethinking the past (evaluating one's own life, actions 
Klishevich \& Sulitskyi, 2021. The Role of Repentance of Convicts in the Process of their Correction and Resocialization

and their results, attitude to the world around them, etc.); personal need for psycho-emotional rest; specific positive actions (attitude to: regime, work, education, socio-pedagogical and psychological work, participation in public organizations, cooperation with public, religious organizations) in the process of resocialization; sincere conscious repentance (its assessment can be carried out in the process of socialization of the convict).

\section{Conclusion}

Thus, we have found indicators that allow us to establish the sincerity of the convicted person's conscious repentance. Structural and formal indicators of remorse assessment: attitude to the regime; attitude to work; attitude to learning; attitude towards participation in public life; attitude towards the collective of convicts. Structural objective indicators for assessing remorse: attitude to crime; attitude towards the victim; attitude towards punishment; attitude to the sentence; attitude towards the consequences of a crime; attitude towards the investigation; attitude to one's own role in a crime (when the crime is collective or group); attitude towards serving the sentence (the general result of structural subjective assessments of repentance).

We believe that the main socio-psychological indicator in assessing sincere, conscious repentance is the person's "attitude" to structural objective and subjective factors.

At the same time, it remains to solve the problem of creating a mechanism (algorithm) for bringing convicts to conscious, sincere repentance. In our opinion, it should contain a set of measures aimed at shaping convicts' understanding, acceptance and awareness not only of the illegality of their own actions, but also of their consequences for themselves and, which is especially important, for the victims. The result of a positive socio-psychological personality change should be a desire to accept punishment and prove the correction by concrete actions.

\section{References}

Aleksejchik, A.E. (1985). Biblioterapiya. Rukovodstvo po psihoterapii. Tomsk: Medicina.

Antonyan, Yu.M. (1991). Prestuplenie i pokayanie. Obshchestvennye nauki i sovremennost', 6, 43-52.

Antonyan, Yu.M. (1996). Psihologiya prestupnika i rassledovaniya. Moskva: Yurist.

Jack, S.J. \& Ronan, K.R. (2008). Bibliotherapy practice and research. School Psychology International, 29 (2), 161-182.

Ilyin, Iv. (1943). Die ewigen Grundlagen des Lebens. Zürich: Aehren Verl.

Kvachev, V.E., Suhinskaya, L.A., \& Tatarevskij, V.A. (2014). Ocenka stepeni priznaniya osuzhdennym svoej viny. Dnepropetrovsk. 
Proceedings of the International Scientific Conference. Volume III, May $28^{\text {th }}-29^{\text {th }}$, 2021. 305-315

Maslova, V.A. (2016). Pokayanie: zhizn' cheloveka ili deyatel'nnostyj koncept ili zhanr. Zhanry Rechi, 1, 94-99.

McCulliss, D. (2012). Bibliotherapy: Historical and research perspectives. Journal of Poetry Therapy, 25 (1), 23-38.

Pakhomov, I.V. \& Grigorenko, A.M. (2019). Social'no-vihovna robota iz zasudzhenimi ta osobami, vzyatimi pid vartu. Bila Cerkva.

Sevastyanov, R.A. (2015). Priznanie viny i raskayanie kak kriterii ispravleniya osuzhdennogo: teoreticheskie aspekty. Vestnik Saratovskoj gosudarstvennoj yuridicheskoj akademii, 1 (144), 177-181.

Shadrikov, V.D. (2006). Pokayanie kak faktor formirovaniya sovesti. Psihologiya. Zhurnal Vysshej Shkoly, 4 (3), 3-13.

Smirnov, D.O. (2005). Grekhe i pokayanii: Put' pokayaniya. Besedy pered ispoved'yu. Novgorod: «Danilovskij blagovestnik».

Smirnov, A.Yu., \& Chikina, O.N. (2016). Ispol'zovanie pritch v psihologicheskoj podderzhke, motivacii, proforientacii. Moskva: Navigatum.

Suprun, M.O. (2016). Osoblivosti duhovnogo vihovannya zasudzhenih ta personalu Derzhavnoï kriminal'no-vikonavchoï sluzhbi Ukrä̈ni. Bila Cerkva.

Tupikova, Z.V. (2016). Mental'naya struktura koncepta pokoyaniya. Naucheyj dialog, 12 (60), 185-196.

Ubyali, S. (2009). Dogmaticheskoe uchenie o tainstve Pokayaniya v katolicheskom bogoslovii. Pravoslavnoe uchenie o cerkovnyh tainstvah, T.3. Moskva.

Vorkachev, S.G. (2012). Utopiya ili pritcha: ideya smysla zhizni v tvorchestve Andreya Platonova. Zhanry rechi, 8, 313-326.

Yakovets, I.S. (2016). Prava lyudini za gratami. Kiï: Asociaciya UMDPL.

Yaroshovec, V.I., Bichko, V.I., \& Bugrov, V.A. (2006). Istoriya filosofi. Kiyv: PARAPAN. 